\title{
PEMANFAATAN TEKNOLOGI INFORMASI BIDANG E-COMMERCE DI TOKO MULIA JAYA
}

\author{
Afdhal Syafnur'), Romy Aulia ${ }^{2)}$, Yori Apridonal ${ }^{3)}$, Alfan Suhendra ${ }^{4)}$, Nur Aisyah Lubis ${ }^{5)}$ \\ ${ }_{1,2,3,4,5}$ Sistem Informasi, STMIK ROYAL, Kisaran \\ email: afdhal23@gmail.com
}

Submit : 18/10/2021| Accept : 01/11/2021| Publish: 30/12/2021|

\begin{abstract}
E-commerce or selling electronically is a marketing and sales activity through internet or digital media online. The purpose of this community service activity is to provide an understanding of the role of electronic sales in an effort to increase sales of UMKM products that have an impact on the welfare of business actors and employees and benefit the people who buy their products. Mulia Jaya is a store that sells women's accessories and clothing, such as clothes, shoes, bags, and other women's accessories. Because it is still relatively new, the marketing carried out has not been maximized, namely selling its products to consumers in the surrounding area only, so it has not been able to attract consumers more broadly. This is the goal of this community service activity, namely to provide an understanding of the use of information technology in the field of e-commerce in marketing and selling Toko Mulia Jaya products so as to increase product sales.
\end{abstract}

Keywords: E-Commerce, Clothing, UMKM

\begin{abstract}
Abstrak
E-commerce atau penjualan secara elektronik merupakan kegiatan pemasaran maupun penjualan melalui media internet ataupun digital secara online. Tujuan dari kegiatan pengabdian kepada masyarakat ini ialah untuk memberikan pemahaman mengenai peran penjualan secara elektronik dalam upaya meningkatkan penjualan produk UMKM yang berdampak pada kesejahteraan pelaku usaha beserta para karyawan dan bermanfaat bagi masyarakat yang membeli produk mereka. Mulia Jaya adalah toko yang bergerak dalam bidang penjualan asesoris wanita dan pakaian, seperti baju, sepatu, tas, dan asesoris wanita lainnya. Dikarenakan masih tergolong baru, pemasaran yang dilakukan belum maksimal yaitu menjual produknya kepada para konsumen yang ada di wilayah sekitarnya saja, sehingga belum dapat menarik konsumen secara lebih luas. Hal inilah yang menjadi tujuan dari kegiatan pengabdian kepada masyarkat ini, yaitu untuk memberikan pemahaman mengenai pemanfaatan teknologi informasi di bidang e-commerce dalam memasarkan dan menjual produk Toko Mulia Jaya sehingga dapat meningkatkan penjualan produk.
\end{abstract}

Kata Kunci: E-Commerce, Pakaian, UMKM

\section{PENDAHULUAN}

Seiring dengan perkembangan teknologi saat ini, tren di dunia bisnis juga semakin bervariasi. Salah satunya ialah digital marketing. Digital marketing merupakan suatu kegiatan pemasaran ataupun dan penjualan suatu produk dengan menggunakan media internet atau digital. Tujuan dari digital marketing yaitu untuk menarik konsumen dan calon konsumen secara cepat (Rengganawati \& Taufik, 2020).

Perkembangan teknologi digital yang sangat pesat tersebut memberikan peluang yang lebih besar bagi para pelaku UMKM (Usaha Mikro Kecil dan Menengah) untuk dapat memasarkan dan menjual produknya bukan hanya secara konvensional (offline), namun juga dapat dilakukan secara online, karena internet merupakan sarana ecommerce yang paling mudah 
dimanfaatkan. Dengan memanfatkan internet sebagai media komunikasi dalam memasarkan produk, diharapkan mampu menjangkau pasar yang lebih luas sehingga semakin banyak yang mengetahui dan membeli produk yang ditawarkan (Sulaksono \& Zakaria, 2020).

Berdasarkan latar belakang tersebut, maka sosialisasi pemanfaatan teknologi informasi bidang e-commerce sangat penting dilakukan kepada para pelaku UMKM di Toko Mulia Jaya untuk meningkatkan penjualan secara global. Dimana Toko Mulia Jaya merupakan UMKM yang berdiri pada tahun 2020 yang bergerak di bidang penjualan asesoris dan pakaian wanita seperti tas, sepatu, baju dan asesoris lainnya.

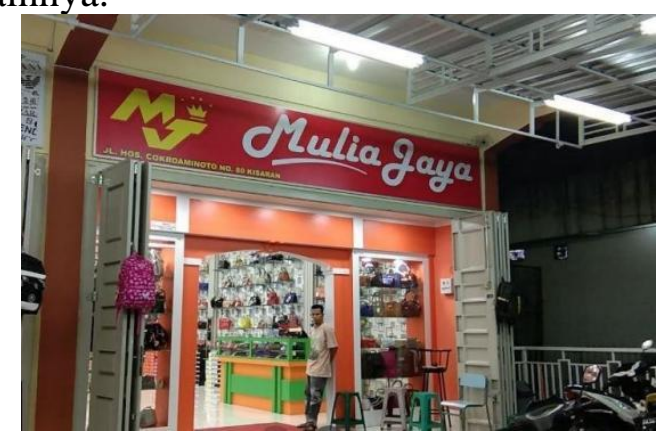

Gambar 1. Toko Mulia Jaya

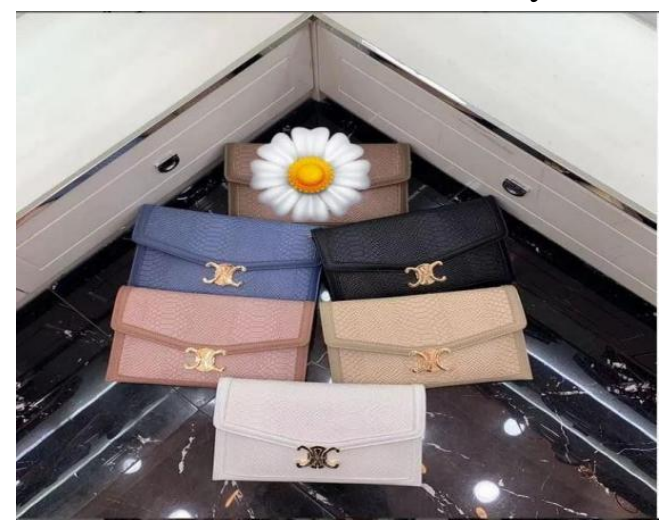

Gambar 2. Produk Toko Mulia Jaya

Tujuan dari kegiatan sosialisasi pemanfaatan teknologi informasi ini diharapkan dapat bermanfaat dalam menambah wawasan dalam teknik pemasaran dan penjualan secara online yang sesuai dengan perkembangan teknologi terkini bagi Toko Mulia Jaya
(Fakhriyyah, Wulandari, \& Kharisma, 2020). Selain itu juga dapat menstabilkan penjualan produk tersebut, sehingga diharapkan dapat meningkatkan omset penjualan produk UMKM (Hapsoro, Palupiningdyah, \& Slamet, 2019).

\section{METODE KEGIATAN}

Kegiatan Pengabdian Kepada Masyarakat (PKM) ini berjudul "Pemanfaatan Teknologi Informasi Bidang E-Commerce Di Toko Mulia Jaya" yang dilaksanakan di Toko Mulia Jaya, Jln. Cokroaminoto, Kota Kisaran, Kabupaten Asahan. Peserta dalam kegiatan adalah pelaku usaha Koowe yang berjumlah 7 orang yaitu pemilik usaha beserta karyawannya. Dilakukan selama 2 hari pada tanggal 25-26 Desember 2021.

Metode yang digunakan dalam kegiatan PKM ini ialah metode ceramah, diskusi dan simulasi. Metode ceramah digunakan untuk memberikan pemahaman dan gambaran bagaimana e-commerce dapat meningkatkan penjualan produk UMKM. Metode diskusi dilakukan guna menggali informasi serta keinginan pemilik dalam meningkatkan

penjualannya. Sedangkan simulasi dilakukan guna mempraktekkan secara langsung penggunaan media internet sebagai media pemasaran ataupun penjualan meningkatkan penjualan produk UMKM.

\section{HASIL DAN PEMBAHASAN}

Dalam sosialisasi ini, narasumber memberikan pemaparan mengenai pentingnya peran penjualan elektronik dalam upaya meningkatkan penjualan produk UMKM. Digital marketing menjadi salah satu media yang sering digunakan oleh pelaku usaha karena kemampuan baru konsumen dalam mengikuti arus digitalisasi, beberapa perusahaan sedikit demi sedikit mulai meninggalkan model 
pemasaran konvesional/dan beralih ke pemasaran modern.

Adapun keunggulan dalam memanfaatkan e-commerce, antara lain:

1. Target bisa diatur sesuai demografi, domisili, gaya hidup, dan bahkan kebiasaan;

2. Hasil cepat terlihat sehingga pemasar dapat melakukan tindakan koreksi atau perubahan apabila diras ada yang tidak sesuai;

3. Biaya jauh lebih murah daripada pemasaran konvensional;

4. Jangkauan lebih luas karena tidak terbatas geografis;

5. Dapat diakses kapanpun tidak terbatas waktu;

6. Hasil dapat diukur, misalnya jumlah pengunjung situs, jumlah konsumen yang melakukan pembelian online;

7. Kampanye bisa dipersonalisasi;

8. Bisa melakukan engagement atau meraih konsumen karena komunikasi terjadi secara langsung dan dua arah sehingga pelaku usaha membina relasi dan menumbuhkan kepercayaan konsumen (Febriyantoro \& Arisandi, 2018).

Disisi lain, e-commerce juga memiliki kelemahan, yakni:

1) Mudah ditiru oleh pesaing;

2) Dapat disalahgunakan oleh pihakpihak yang tidak bertanggungjawab;

3) Reputasi menjadi tidak baik ketika ada respon negatif;

4) Belum semua orang mengggunakan teknologi internet atau digital (Febriyantoro \& Arisandi, 2018).

Banyak pelaku UMKM yang telah menggunakan media sosial sebagai alat pemasarannya. Media sosial adalah alat komunikasi masa depan, kumpulan alat dan platform berbasis internet yang tak terhitung jumlahnya yang dapat meningkatkan infomasi yang dibagi. Dengan terbentuknya media baru ini membuat pengiriman teks, foto, suara, video, dan informasi semakin mudah dan sering oleh kalangan pengguna internet. Media sosial tidak hanya digunakan oleh pengguna internet untuk sekedar bersosialisasi saja tapi juga melakukan bisnis (Rini \& Shihab, 2019).

Adapun manfaat penggunaan media sosial dalam kegiatan usaha seperti:

1. Mudah mengetahui informasi tentang pelanggan melalui media sosial;

2. Efektif dalam menentukan target market;

3. Mudah mencari pelanggan baru dan memperluas target pasar;

4. Mudah menerima umpan balik dari pelanggan;

5. Mengembangkan target pasar dan menjaga daya saing dengan pesaing usaha lainnya;

6. Meningkatkan pengunjung situs web dan peringkat mesin pencari;

7. Informasi dapat tersampaikan dengan lebih cepat;

8. Membantu konsumen supaya lebih mudah menjangkau pelaku usaha;

9. Lebih dekat dengan konsumen;

10. Meningkatkan kesadaran merek dan promosi dengan biaya minimal (Nikmah, 2017).

Berikut ada beberapa media sosial yang digunakan dalam kegiatan bisnis, seperti: Facebook, Twitter, Instagram, Google+, Linkedln, Pinterest, Youtube, serta Tiktok (Nikmah, 2017). Dan media sosial yang digunakan narasumber sebagai bahan praktek simulasi yaitu Instagram.

Salah satu media sosial populer saat ini yang dijadikan untuk kegiatan pemasaran adalah Instagram. Instagram ditetapkan sebagaiaplikasi media sosial keempat yang paling sering digunakan pada tahun 2017 setelah Youtube, Facebook, dan Whatsapp berdasarkan survei WeAreSocial.net (Databooks 2018). Instagram merupakan aplikasi layanan berbagi foto yang memungkinkan penggunanya untuk mengambil foto, dan 
memberikan filter pada foto, kemudian menyebarluaskannya dengan memposting di media sosial seperti Facebook, Twitter, dan lainnya.(Ramadan, 2021).

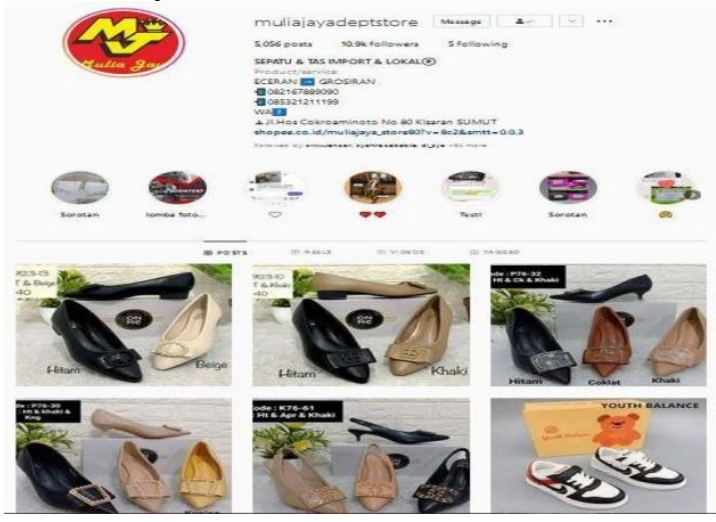

Gambar 3. Media Sosial Instagram sebagai media promosi dan penjualan

Berdasarkan observasi yang dilakukan terhadap Toko Mulia Jaya, dapat digambarkan bahwa media sosial yang digunakan selama ini oleh pemilik usaha adalah Whatsapp sebagai media pemasaran ataupun promosi produknya. Akan tetapi hal ini kurang optimal, dikarenakan yang melihat promosi tersebut hanya orangorang yang ada dalam kontak si pemilik, sehingga proses pemasaran tidak berjalan dengan optimal. Adapun penggunaan Instagram hanya sebatas memasukkan foto dan membuat status sebagai media pemasaran. Padahal pada Instagram tersedia fitur Instagram Ads untuk menarik konsumen dan memperluas jangkauan usahanya.

Pengenalan digital marketing kepada UMKM Toko Mulia Jaya memiliki tantangan tersendiri. Akan tetapi dengan dilakukan diskusi mengenai metode pemasaran dan penjualan berbasis teknologi atau digital marketing, maka dapat dipahami dengan mudah dan digunakan oleh pelaku dan karyawan UMKM Toko Mulia Jaya.

Setelah mengikuti kegiatan sosialisasi tentang digital marketing, diharapkan pelaku usaha Toko Mulia Jaya ini mampu:
1) Memanfaatkan teknologi informasi semaksimal mungkin sehingga dapat membantu mengembangkan usahanya dan dapat bersaing secara global dengan para pelaku usaha lain.

2) Secara aktif memanfaatkan digital marketing sehingga dapat menjangkau pasar serta menarik konsumen secara lebih luas (Maulidasari \& Setiyana, 2020).

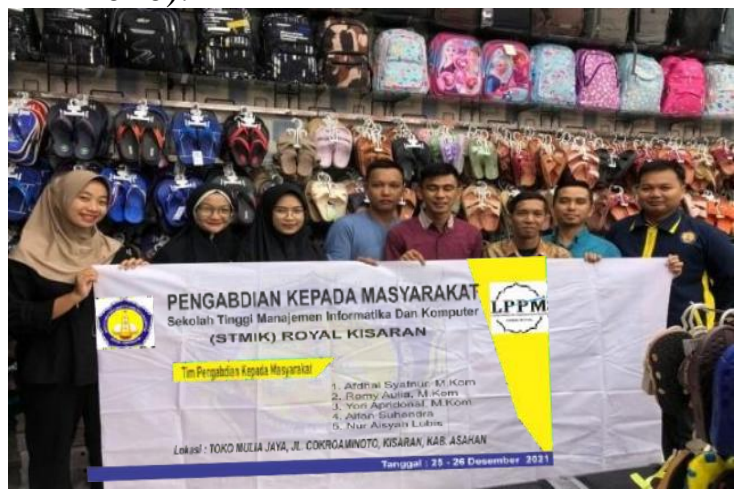

Gambar 4. Tim Pengabdian beserta pelaku usaha

\section{SIMPULAN}

Hasil dari kegiatan Pengabdian kepada Masyarakat yang dilaksanakan pada tanggal 25-26 Desember 2021 di Toko Mulia Jaya ini ialah diberikannya pemahaman bagi para pelaku UMKM mengenai pentingnya digital marketing dalam memasarkan, menjual ataupun mempromosikan produk UMKM, sehingga pelaku UMKM dapat menjual produknya tidak hanya di wilayah setempat, tetapi juga dapat mengembangkan usahanya secara lebih luas atau global dengan bantuan media sosial sebagai alat pemasarannya.

\section{DAFTAR PUSTAKA}

Fakhriyyah, D. D., Wulandari, Y., \& Kharisma, C. (2020). Sosialisasi digital marketing dan inovasi produk pada ukm gula merah guna mempertahankan ekonomi di masa pandemi covid-19. JP2M (Jurnal Pembelajaran Pemberdayaan Masyarakat), 1(4), 311-317. 
Febriyantoro, M. T., \& Arisandi, D. (2018). Pemanfaatan Digital Marketing Bagi Usaha Mikro, Kecil Dan Menengah Pada Era Masyarakat Ekonomi Asean. JMD: Jurnal Riset Manajemen \& Bisnis Dewantara, 1(2), 61-76. https://doi.org/10.26533/jmd.v1i2.1 5

Hapsoro, B. B., Palupiningdyah, \& Slamet, A. (2019). Peran Digital Marketing sebagai Upaya Peningkatan Omset Penjualan Bagi Klaster UMKM di Kota Semarang. ABDIMAS: Jurnal Pengabdian Kepada Masyarakat, 23(2), 117-120. https://doi.org/http://dx.doi.org/10.15 294/abdimas.v23i2.17880

Maulidasari, C. D., \& Setiyana, R. (2020). Sosialisasi Digital Marketing pada Usaha Mikro Kecil Menengah (UMKM). Jurnal Pengabdian Masyarakat: Darma Bakti Teuku Umar, 2(1), 63-73. https://doi.org/10.35308/baktiku.v2i1 .2050

Nikmah, F. (2017). Kajian Tentang Pemasaran Online Untuk Meningkatkan Peluang Bisnis. Adbis: Jurnal Administrasi Dan Bisnis, 11(1), $\quad$ 47-56. https://doi.org/10.33795/jadbis.v11i1.19
Ramadan, A. (2021). Efektivitas Instagram Sebagai Media Promosi Produk "Rendang Uninam." Jurnal Sains Komunikasi Dan Pengembangan Masyarakat [JSKPM], 5(1), 64-84. https://doi.org/10.29244/jskpm.v5i1. 796

Rengganawati, H., \& Taufik, Y. (2020). Analisis Pelaksanaan Digital Marketing pada UMKM Tahu Rohmat di Kuningan. KOMVERSAL: Jurnal Komunikasi Universal, $\quad 6(1), \quad 28-50$. https://doi.org/10.38204/komversal.v 6 i1.496

Rini, M. N. A., \& Shihab, M. R. (2019). Strategi Media Sosial Untuk Pengembangan Umkm. Jurnal Terapan Teknologi Informasi, 2(2), 159-170. https://doi.org/10.21460/jutei.2018.2 2.125

Sulaksono, J., \& Zakaria, N. (2020). Peranan Digital Marketing Bagi Usaha Mikro, Kecil, Dan Menengah (UMKM) Desa Tales Kabupaten Kediri. Generation Journal, 4(1), 4147. https://doi.org/10.29407/gj.v4i1.139 6. 